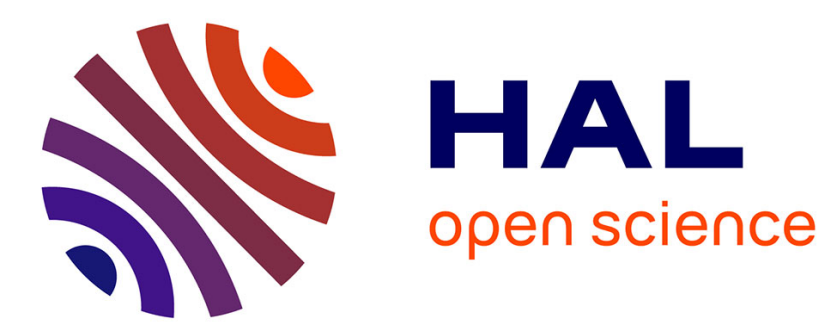

\title{
On gold recycling. A physicochemical point of view Maria Guerra
}

\section{To cite this version:}

Maria Guerra. On gold recycling. A physicochemical point of view. Archaeometry, 2021, 10.1111/arcm.12710 . hal-03325343

\section{HAL Id: hal-03325343 \\ https://hal.science/hal-03325343}

Submitted on 27 Nov 2021

HAL is a multi-disciplinary open access archive for the deposit and dissemination of scientific research documents, whether they are published or not. The documents may come from teaching and research institutions in France or abroad, or from public or private research centers.
L'archive ouverte pluridisciplinaire HAL, est destinée au dépôt et à la diffusion de documents scientifiques de niveau recherche, publiés ou non, émanant des établissements d'enseignement et de recherche français ou étrangers, des laboratoires publics ou privés. 


\title{
INVITED REVIEW
}

\author{
ON GOLD RECYCLING. A PHYSICOCHEMICAL POINT OF VIEW \\ Archaeometry, 2021 \\ https://doi.org/10.1111/arcm.12710 \\ MARIA F. GUERRA \\ MONARIS, UMR 8233 CNRS - Sorbonne Université, Campus Pierre et Marie Curie, 4 place Jussieu, 75005 \\ Paris, France - Email: maria.guerra@cnrs.fr
}

\begin{abstract}
Perceived as a material and a colour, gold has assumed major societal roles. It has been used as a medium of exchange and in the production of objects with cultural, social and religious meanings. Being a finite resource, gold has often been subjected to recycling processes. Over time, some objects were reused to make new objects and others were melted down to use the resulting gold as raw material. These operations can be approached using an appropriate analytical protocol. Analytical challenges raised by studies on the reuse and recycling of gold are discussed in the given examples, some of them focusing on coins and others on jewellery and ritual objects. To illustrate the different levels of analytical difficulty, some of these objects were made during times of gold scarcity and others in periods of gold influx.
\end{abstract}

\section{KEYWORDS: GOLD, REUSE, RECYCLING, ANALYSIS, ALLOYS, JEWELLERY, COINS}

\section{INTRODUCTION}

Gold is one of the most remarkable materials available in nature for the communication of ideas, because visually it can be perceived as both a material and a colour (Okazawa et al. 2011). Colours act as visual signals that commonly serve to catch attention, to transmit information and to affect the emotions of the viewer (Humphrey 1976). Therefore, by assigning a value to gold and by exploiting its properties, it was very early possible to gain acceptance for gold as a medium of exchange ('money') and to use it to convey indications of social status, political signs and religious codes. Since then, gold has thus played two important societal roles, differently perceived, even if sometimes a conceptual convergence is observed (Oakley 2017).

Given its important societal role and its low crustal abundance (0.002 ppm, Rankin 2011), gold has often been recycled. This mainly happens when objects are no longer useful (e.g. broken, out of fashion...) or when 'fresh' gold is temporarily unavailable. "Recycling gold" is, however, a much more complex process than just melting down objects, because it involves many highly controlled operations. Some of these operations have been carefully recorded in ancient documents, like the texts of Mari ( $2^{\text {nd }}$ millennium BC), where the reported dismantling of gold objects includes control of weights and compositions of all components, even the smallest ones, and the value attributed to the work of the goldsmith (Joannès 1989). In the Ebla clay tablets, more ancient ( $3^{\text {rd }}$ millennium BC), the smallest gold piece reported weighs only $0.08 \mathrm{~g}$ (Archi 2002, 2015).

Dismantled components have not necessarily been melted down, some of them may have been reused. On the basis of the particular characteristics of gold objects, I have chosen to use here two terms to express the possible recycling processes. The first term, recycling, is associated with the melting down of gold objects to obtain the raw material necessary for the production of new objects. However, when the function of an object is modified, or when the object or part of it becomes or integrates a new object, I preferred the term reuse. While in both cases the object is "recycled", the two operations raise distinct analytical questions, easily explained in the case of coins. Gold coins are usually made under the control of an administration or a state authority. When a head of state changes or a new weight standard is introduced, coins in circulation become obsolete and are recalled to be melted down and produce new blanks. In this case (recycling), the elemental or isotopic composition of the gold coins provides the elemental and isotopic characteristics of the monetary gold, i.e. its signature. The signature can sometimes be associated with a source or supply of gold and used to track it throughout recycling processes. However, depending on the value given to the new coins and the defined monetary base, it may be necessary to refine the "gold" obtained by melting down the coins and to add "metals". Added metals can come from a wide variety of sources (Ponting 2020): coins, fresh metals, taxes paid to the state, booty, stored objects and even the gold parts of statues. For example, after the end of the Social War, the allied coinage was melted down by the Romans to increase the monetary liquidity at Rome, and in 82 , by decree of the senate, gold and silver sacred treasures were melted down to make coins (Kay 2016). In this case, the signatures of the original and final monetary gold are different and this may raise analytical difficulties, some of which are discussed below.

The recycling of coins is a costly operation that involves an organised and highly controlled system, and skilled crafts. Reuse is a different operation. Revaluation of pre-existing coins is a cheap alternative to the making of fresh blanks. Counterstamping, overstriking, holing and cutting, are operations employed in difficult periods and when emission of a huge number of coins is necessary (Grierson 1982; Wood 1914). For example, in the $18^{\text {th }}$ century nearly three million of silver coins, almost entirely Spanish pieces of 8 reales, were counterstamped in the Royal 
Mint of England with King George III's head for recirculation (Manville 2000). In this case, the questions raised relate to the technology used and not to the composition of the coins.

Identical processes of reuse and recycling can be described for jewellery and other gold objects. However, if to avoid costly production it can be considered the direct reuse of certain components (e.g. the most common or "fashionable" gold beads), these operations become more complex to consider when the objects are composite. Indeed, the simple revaluation operations used at the mint are replaced by all the possibilities offered by the art of the goldsmith. In this brief contribution, it is impossible to cover all the questions raised by a material like gold, by the many sorts of gold objects made in the past and by the repertoire of techniques employed by the goldsmith, and additionally list the analytical challenges associated with gold reuse and recycling. My aim remains to give some clues about the main questions raised by the reuse and recycling of gold objects, emphasising those that, from my perspective, can be addressed by using science-based methods. Therefore, if the last section of this text is devoted to recycling, I propose a separate section with some examples of reuse. As, in my opinion, a good understanding of the objects is one of the most essential steps in the study of reuse and recycling, I have chosen to briefly outline in the following section the main properties of gold and the main sorts of objects.

\section{DAZZLING SHINING GOLD}

Gold is not suitable for making tools or weapons. It is therefore conceivable that it had at first, at an indeterminated date, a minor (aesthetic) role in society. The number of excavated copper objects increases from the 7th millennium $\mathrm{BC}$ onwards (Yalçin 2017). It is therefore surprising that the earliest gold objects, found in Bulgaria, date from mid-5th millennium BC, and that only a few come from Durankulak and Tell Yunatsite (Avramova 1991) while about 3000 were found in Varna (Ivanov 1982). In neighbouring Greece and the Aegean Sea only a few have been found dated to end-5th - mid-4th millennium BC (Alram-Stern 2012, Maxwell et al. 2018). During the 4th millennium BC gold objects become more complex. An example is the Late Uruk dog-shaped pendant from Susa made by lost-wax casting and hard-soldering (Duval et al. 1987). Lost-wax casting was in use for copper already in the 6th millennium BC, as demonstrated by an amulet excavated in Mehrgarh (Thoury et al. 2016). This shows that gradually, the properties of gold have been extensively exploited.

The mechanical properties of gold, such as malleability, elasticity, tensile strength (Grimwade 2009; FischerBühner 2010), allow its transformation into many sorts of objects with symbolic or aesthetical significance by using simple shaping processes. However, it is its physical properties, in particular the optical ones, that make gold a stimulating material. Such as in a film or in a painting, where colour and lighting are used to help us in the understanding of a scene (Wieck 1969), the perceived visual aspect of gold objects (Todd and Norman 2018; Fleming 2014) can be enriched by illumination (Motoyoshi et al. 2007; Okazawa et al. 2011; Matsumoto et al. 2016). Transmission, refraction, absorption, scattering and reflection of light on gold (Tilley 2011) can be used to modify the appearance of a shape and to bring to light both glitter and gloom.

It certainly took a while to get to this point. The colour of the earliest gold objects should have been a result of chance. Native gold, which is recovered easily by washing and panning in alluvial deposits, is an Au-Ag-Cu alloy of varying colours. Alluvial gold generally contains small amounts of copper (Moles et al. 2013; Chapman et al. 2021), although in some deposits its value may be higher (in the Salair Ridge in southwestern Siberia, gold contains up to $4 \mathrm{wt} \% \mathrm{Cu}$, Nevolko et al. 2019), and quite variable amounts of silver (Boyle 1979, 1987). For example, in the Southern Apuseni Mountains gold contains up to $42 \mathrm{wt} \% \mathrm{Ag}$ (Pop et al. 2011; Popescu et al. 2013) while gold grains from the Miocene deposit of Las Médulas contain less than $1 \mathrm{wt} \% \mathrm{Ag}$ (Pérez-García et al. 2000). In the colour ternary diagram (Roberts and Clarke 1979; Rapson 1990), the first gold is pale greenish yellow while the second is yellow. It is not only the colour of gold that is important, there is tendency to overlook the importance of how it "shines". The reflectivity of the gold alloys also varies with the quantities of alloying elements, increasing with growing amounts of silver (Shiraishi and Tilley 2014), the metal with the highest reflectance and minimum emittance in the infrared (Macleod 2011). Therefore, by adding specific amounts of silver to gold, some civilizations were able to use a dazzling shiny gold still yellow in colour (Guerra 2020).

The more or less dazzling shining yellowish, greenish, whitish... gold nuggets that can be recovered in alluvial deposits may explain at least part of the "sorts" of gold mentioned in some documentary sources. In the Qatna inventories (mid-2 $2^{\text {nd }}$ millennium BC, Syria, Novak 2004), some varieties of gold are named on the basis of the geographical origin of the metal and others by their colour: green gold, light (perhaps white) gold, electrum, red gold, etc. (Bottéro 1949). The perception of hue is also expressed. The most valuable quality reported in the Qatna inventories is the yellow gold with a red hue (Thavapalan 2020), which indeed corresponds to the purest gold alloys in the colour ternary diagram. The emphasis on colour and hue in ancient documents evidences early need for intentional gold alloys. This involves refining native gold and adding alloying elements, production steps that are difficult to date, even if archaeological vestiges found in Anatolia indicate that salt cementation was in use in the 1st millennium BC (Craddock 1999).

The many sorts of gold objects that have been made in the past had several functions. Only part of them were made in large workshops, have travelled far, or have reached us. It is difficult to know to what extend those that reached us are representative of the actual production. Among them are many coins hidden during periods of political 
instability and warfare (the cache at Trier contained $18.5 \mathrm{~kg}$ of Roman gold coins, Gilles 2013), which explains why they have not been retrieved (Howgego 1995; Heesch 2017). Most of the gold jewellery that reached us has been found in tombs, which can be dated. Many other objects were contained in hoards. When the hoards contain coins, a terminus post quem for the deposition can be suggested. However, some of them are difficult to interpret. Those containing ingots and fragmented jewellery and coins have been associated with both recycling operations (by goldsmiths) and trade exchange, and those containing 'pre-portioned' ingots have been associated with a premonetary system (Golani and Sass 1998; Le Rider and Verdan 2002; Thompson 2003; Singer 2015; Eshel et al. 2018). I would underline those containing gold objects, often dated to the Bronze Age, that have been found, curiously, buried in the ground somewhere far from any habitat and which could be either votive offerings or objects collected and hidden for trade and recycling (Harding 2000; Cooper et al. 2020). One of the most puzzling, containing gold spirals, was found at Hradec Králové in Bohemia (Filip 1948, pl. 30). Others are heavy. Among those found in the Iberian Peninsula (Garcia Bellido 2011), often containing objects spanning a long chronology (Pingel, 1992; Perea 1994; Guerra and Tissot 2021), is the Treasure of Caldas de Reis, which weighs $15 \mathrm{~kg}$, but whose initial weight is unknown (Ruiz-Galvez 1995). Frequently sold by weight to goldsmiths for recycling (Cardozo 1937), many of these objects and hoards have been melted down, at unspecified times.

The questions raised by non-contextualized objects are therefore, difficult to tackle. When it is difficult to understand the function of the analysed objects and their date of manufacture is unknown, the analytical results obtained are difficult to interpret. The success of an analytical study also depends on the objects selected for the study, as shown in the examples given in the two following sections.

\section{ON GOLD REUSE}

During economically and socially difficult times, when raw materials were not available, reuse avoided the expensive metallurgical operations associated with recycling. Reuse reduces costs not only by saving time, material and energy but also by avoiding the need for expensive specialised artisans, often not available when no one can afford to buy very expensive items. This is the case with the Indians of South America. In Araucania and Patagonia, the Mapuche, who did not have access to raw materials, used coins to make jewellery. If the coins could be melted down, most of them were either reshaped (by plastic deformation followed by cutting) or directly integrated into the jewellery (Joseph 1928; Guerra and Nuñez-Regueiro 2012; Nuñez-Regueiro and Guerra 2016; Guerra 2020). Figure 1a shows a ritual earring whose decoration has been erased for reuse after redecoration and Figure $1 \mathrm{~b}$ shows a finger-ring whose bezel is a heavily worn 10 cents Argentinian coin made in 1881-83 at the Buenos Aires mint.

Reuse was also employed in early periods by societies with access to gold, e.g. in Ancient Egypt, where the most common types of gold beads appear to be both "fresh" and heavily worn (Guerra et al. 2021a). Among these types are the tiny beads often used as spacers in strings, which appear with different levels of wear within a group of jewellery (same tomb) and sometimes within the same string, and in two sort, tubular- and ring-shaped (Figure 1c). These two sorts were reported early for gold (at Kerma, Reisner 1923) and copper (at Mostagedda, Brunton 1937). A string of tiny gold beads found by Flinders Petrie on the mummified body of a young child buried with a woman at Qurna (1 $7^{\text {th }}$ Dynasty), also contains different sorts of tiny beads (Troalen et al. 2014). These beads, which also have different dimensions, colours and shapes, are the result of mixing many batches and many artisans' work. The traces of use-wear identified on their surface show that they are a reuse of beads from other strings, as observed in jewellery from more ancient tombs (Guerra 2021).

The questions raised by reuse can therefore be approached by searching under different lights and at different depths and scales for traces of use-wear and for particular manufacturing details. The composition of a gold object can also shed new light on reuse when studies of wear and manufacturing technology do not provide a specific indication. To illustrate this, it is interesting to consider the miniature votive production of the Incas. Small figurines in gold, in silver and in spondylus shell, sometimes dressed with textile garments fasten with metallic pins (tupus), were made by the Incas to be offered in sacred places or during the capacocha ceremony, a ritual in which children were sacrificed (Benson 2001; Reinhard and Ceruti 2005). These figurines, with standardised iconography, were shown to be manufactured using standard technology, e.g. the traditional hollow ones are made by assembling the same components (Guerra et al. 2017; Vetter 2018). Two, both hollow, stand out, however, because they are bicolour. One, made by assembling a silver upper part and a copper lower part (Sierra and Guerra 2017), was found at Paucartambo (Cusco, Peru) and on the basis of stylistic and compositional criteria (votive objects have no traces of wear) it has beeb suggested that it was made by reuse (or repaired) at a time after the arrival of the Spanish (Vetter and Guerra 2017). The second figurine is shown in Figure 2. Found in an undetermined context in Pachacamac (Lima, Peru), it consists of an upper part in gold and a lower part in silver. The iconographic details and the technology are those expected for traditional figurines. The alloys were analysed using a handheld XRF (upper part: $69.1 \mathrm{wt} \% \mathrm{Au}, 30 \mathrm{wt} \% \mathrm{Ag}, 1.3 \mathrm{wt} \% \mathrm{Cu}$; lower part: $93.7 \mathrm{wt} \% \mathrm{Ag}, 6.1 \mathrm{wt} \%$ $\mathrm{Cu}$ ). When plotted with data published for other figurines and tupus (from Guerra and Nuñez-Regueiro 2017 and Guerra et al. 2021b) a good agreement is observed. Indeed, the intentional gold alloy contains the silver contents necessary to obtain the light yellow gold colour with high reflectivity that has been shown to characterise this 
standardised production, and the silver alloy is rich in silver as expected for the hollow pieces. The latter is in addition identical to the alloys used at Paucartambo, where the other bicolour figurine was found. Therefore, these bicolour figurines can result from the reuse of figurines (perhaps to repair) after the period of contact, when precious metals and Inca goldsmiths sufficiently skilled to produce hollow figurines have become rare.

\section{ON GOLD RECYCLING}

When gold objects are melted down and become raw material, the analytical protocol needed to study recycling processes must establish a compositional signature for the gold. Among the techniques potentially useful in this type of research are those that analyse the elemental or the isotopic composition of the objects. Although information is lost during metallurgical processing (gold is worked using a thermomechanical chaîne-opératoire), a few elements that remain in gold can be associated with a certain source of gold (sometimes a deposit or mining region), mainly those that are not affected by the high temperatures attained. Therefore, this approach postulates that the elemental and isotopic signature of the object represents (with high confidence level) that (unique) of the exploited gold source, which increases the difficulties in tracking gold throughout recycling as the objects themselves also pose challenges. Statistically, they must constitute a representative sample of a given population, which is easier to obtain in the case of coins than in the case of jewellery. Coins are mass-produced objects and a series of coins is made typically in one mint using the same gold, technology and dies. Therefore, it is possible, for instance, to relate the signature of a "Macedonian gold" used around $340 \mathrm{BC}$ with the composition of the staters of period I (c. 345-336 BC, Le Rider 1977) issued in Pella by Philip II. Unlike the coins, the jewellery items found in a necropolis and even those contained in the same tomb can date from different periods and be made from gold of different origins. Funerary jewellery was made a priori at a date close to the death of the buried person, while the other jewellery was made at an undetermined period in the life of the deceased or even been in the family of the deceased for decades. For example, Tutankhamun was buried with funerary jewellery, but the ear ornaments with a falcon with spread wings show traces of use-wear (Carter card 269, Wilkinson 1971), indicating that they were made long before his death and therefore perhaps in another workshop.

While understanding the objects is a crucial step when setting up an analytical protocol, it is also necessary to define the query and establish the analytical difficulties associated with the objects. For example, gold objects often have to be analysed in situ using non-destructive techniques (Guerra 2008, 2020), which makes it difficult to perform studies on gold recycling. However, recent development of portable laser ablation sampling devices for trace elements and isotopes analysis by ICPMS (Glaus et al. 2012, 2013) opens up new possibilities. Nevertheless, an "experienced eye" can identify under a stereomicroscope the presence or absence of PGE inclusion, which, when present, indicate the use of alluvial gold (but their absence cannot be used to eliminate this possibility). This is the case of a Merovingian finger-ring found on a male's body buried in Louviers (Eure, France), with signs of extensive wear (Figure 3). Consisting of an engraved bezel containing numerous PGE inclusions soldered onto a decorated hoop without PGE inclusions, the distinct tool marks indicate manufacture by different goldsmiths and suggest a repair. PIXE analysis revealed the use of two gold alloys containing different amounts of silver, but, among the measured minor and trace elements, only the amounts of tin have shown to be different ( $480 \mathrm{ppm}$ in the bezel and $3200 \mathrm{ppm}$ in the hoop). Given the growing famine of gold under the Merovingian leading to a transition from gold to silver (Metcalf and Merrick 1967, Sputfford 1988) and the frequent presence of coins in burials (Lafaurie 1971), sometimes as jewellery (Codine-Trécourt 2014), it is possible to suggest for the bezel the use of gold obtained by recycling. Given the context, Byzantine jewellery, which contains PGE inclusions (Ogden 1977; Craddock et al. 2010), or Byzantine coins, which circulated in Gaul (Lafaurie 1984), are possible sources. However, the hoop is made from gold not containing PGE inclusions. The amounts of silver and tin contained in Merovingian coins (Labrousse and Lafaurie 1987; Blet-Lemarquand et al. 2010) and jewellery (Périn et al. 2005, Guerra 2014a, 2014b; Guerra and Stutz 2019) have been reported in Figure 3 with the finger-ring and some gold beads also excavated at Louviers. The high amounts of Sn, not correlated with the growing amounts of silver, are the same in the jewellery and the coins, and therefore in some way characteristic of "Merovingian gold", but a consequence of a smoothing of the composition caused by continuous recycling of coins and objects, without the introduction of "fresh" metal. As coins issued by the Visigoths have also undergone a sequence of debasement reforms by lack of gold (Bartlett et al. 2017), Visigothic gold jewellery and coins from Spain and Portugal (Guerra 2000; Guerra and Roux 2002; Guerra et al. 2007) were plotted in Figure 4, showing that emerges a chemical pattern identical to the Merovingian one. Byzantine (Morrisson et al. 1985; Jonson et al. 2014) and Roman (Poirier 1983) gold coins added to the diagram (all contained in the rectangle) do not follow the same type of chemical pattern.

While it is difficult to approach recycling in periods of gold scarcity, the analysis of certain trace elements or isotope ratios can provide reliable data on gold used either in the earliest periods (used as found and with low levels of recycling) or in times of gold influx. The signature of the object represents that of the source of gold. These studies often combine an accurate determination of lead isotope ratios and a highly sensitive trace element analysis. For example, Standish et al. (2015) were able to suggest the alluvial deposits in south-west Britain as sources of Irish Chalcolithic and Early Bronze Age gold, and Nocete et al. (2018) suggested as source of South 
Spanish goldwork from the same period the mineralization zone of Ossa Morena, in the Central-Iberian zone of the Variscan Belt (Piña 2019). Analytical difficulties araise when, for more recent periods, the amounts of lead contained in the gold alloy are not associated with the gold but with the added alloying elements or with the refining process. Other authors have determined in addition to the elemental composition of gold and the lead isotope ratios, the elemental and isotopic composition of PGE inclusions (Os isotope ratios). Recently, Jansen et al. $(2016,2021)$ used this protocol to analyse gold jewellery from the Early Bronze Age graves excavated at Ur and on the basis of the data obtained they suggested the exploitation of gold sources located in the Tethyan Eurasian metallogenic belt, perhaps the placer deposits at Takab in Iran and at Samti in Afghanistan, and underlined the use of gold containing a high level of $\mathrm{Pb}$, not correlated with $\mathrm{Ag}$, and amounts of $\mathrm{Cu}$ reaching almost $6 \mathrm{wt} \%$.

I would like to point out that although a priori not made from Iranian or Afghan gold, other gold objects from neighbouring regions have the same type of composition. Dated to the same period as the Ur jewellery, Egyptian Predynastic (Gale and Stos-Gale 1981) and First Intermediate Period (Guerra et al. 2021c) jewellery also contains quite high copper contents. Made more recently, some Western Asiatic gold coins contain high $\mathrm{Pb}$ levels not correlated with Ag. Alexander type staters issued in Babylon and Sardis, resulting from the melting of Persian treasures (Mørkholm 1991), are in this case despite their high gold contents, reaching more than 99 wt\% (Gondonneau et al. 2002), as well as the first Lydo-Milesian electrum coins (Craddock et al. 2005; BletLemarquand and Duyrat 2020), particularly those with a lion's head issued in Sardis.

Unlike isotopic analysis, accurate elemental analysis of PGE inclusions does not provide any indication of gold sources (Meeks and Tite 2008). For example, the numerous inclusions analysed by SEM-EDS and $\mu$ PIXE in Egyptian jewellery excavated at Riqqa, Qurna, Haraga, Thebes, and other sites (Troalen et al. 2014, 2015, 2019, Miniaci et al. 2013, Troalen and Guerra 2016, Guerra and Pagès 2019) did not reveal any clues to the origin of gold. Two highly worn objects stand out however, for the quantity and composition of their PGE inclusions (Guerra and Pagès 2019). The blue scarab set in a gold frame and the gold armband (inscribed using the ancient form of hieroglyph "iah", the first with Ahhotep and the second with Ahmose) date from the Second Intermediate Period, when northern Egypt was ruled from Avaris (Bietak 1996). The composition of their PGE inclusions (Lemasson et al. 2015) is identical to those analysed in objects contained in the Aigina treasure, some of which were made in the Hyksos tradition (Fitton et al. 2009). As the Theban kings brought "gold, lapis lazuli, silver, turquoise" from the many military actions against the Hyksos (Montet 1956), it is possible to suggest for these two objects that they could have been made from recycled gold or by reuse of gold components.

Beyond analysis of PGE inclusions, platinum and palladium, which are more soluble in gold, can also be used with other trace elements such as tin to characterise gold from particular sources, exploited during periods of important inflows of gold. In this case, the recycling of the old stocks does not change the signature of a new gold. In addition to ICP-MS, non-destructive XRF with synchrotron radiation and WDS detection (D2XRF) can also successfully be used, as the detection limit for platinum in gold is as low as 1 ppm (Radtke et al. 2016). This is the detection limit attained for this element by proton activation analysis, the technique used to characterise and track Colombian and Brazilian gold in the $17^{\text {th }}-18^{\text {th }}$ centuries (Guerra 2004, 2005, 2014b). The same technique was used to characterise other monetary gold sources, among which those used in the Islamic Empire. For example, it was possible to characterise and track West African gold by analysing gold nuggets and dinars issued by the Almohads and Almoravids in Africa and Spain. (Roux and Guerra 2000; Gondonneau et al. 2000; Gondonneau and Guerra 2002).

Data collected by analysis of large sets of well-dated coins, issued in precise mints, some situated in the gold mining regions or along the routes taken by gold, are statistically significant enough to be used as "databases" for other studies including those on gold recycling. This is the case of a study carried out on the gold ingots found in a sunken Barbary pirate ship in Salcombe Bay, south-west coast of England, with dismantled and fragmented gold jewellery that appears to have been prepared for recycling, and over 400 dinars issued in Morocco. The results obtained by ICP-MS for the objects from Salcombe were plotted in Figure 5 with data previously obtained for West African gold nuggets and coins, as well as Portuguese coins issued during Portuguese control of the goldbearing region of Elmina in Ghana (Guerra and Magro 2000). The jewellery, coins and ingots from Salcombe form a group (no.1). A good agreement is observed for this group, the West African nuggets and dinars and the Portuguese coins, confirming the use of West African gold to make the objects from Salcombe. Therefore, the ingots can result from the recycling of the jewellery and the coins. No other gold objects appear to have been melted down to make these ingots. Indeed, as the dinars found at Salcombe Bay date the shipwreck to mid-17th century, Colombian and Brazilian coins and ingots (characterised by high amounts the first of platinum and the second of palladium) have been added to the diagram, showing that they form, as expected, separate groups (no.2).

\section{CONCLUDING REMARKS}

Gold has been used in the past to make a wide variety of objects, but being a finite resource and a valuable material, gold has been regularly reused and recycled. While recycling involves the use of the gold as a raw material, the reuse of jewellery and coins avoids many of the costly manufacturing processes. Studies on questions raised by reuse and recycling are analytically different, as the first are based usually on the study of the manufacturing 
technology (which may include analysis of the alloys) and wear of the objects, while the second rely on the search for an elemental or isotopic signature of gold.

Studies on recycling are carried out with varying degrees of success depending on the circumstances, because this approach postulates that the signature of an object represents that (unique) of the source of gold. Since gold is worked using a thermomechanical chaine-opératoire, only a few elements and isotopes provide reliable data to be associated with a gold supply, sometimes a gold deposit. Consequently, recycling operations remain difficult to tackle in times of gold scarcity, as continual recycling without the addition of "fresh" metal results in a gold of smooth composition, and no clues to its origin can be perceived. The same situation occurs when gold from many different sources is mixed.

Nevertheless, in the case of early gold, used as found and subjected to low levels of recycling, as well as in period of important inflows of gold, the elemental or isotopic signature of the gold objects should represent with high confidence level that of the exploited source of gold. When gold from two sources with very different signatures is mixed, it is also possible to track each of them during recycling.

However, it is also necessary to consider the extent to which the objects selected for a specific study are representative of a source of gold or of a recycling process. The probability of obtaining an elemental or isotopic signature of a certain gold is higher by analysis of coins than by analysis of jewellery. Coins are mass-produced items, requiring access to large quantities of metal, often containing precise indications of when and where they were issued, while groups of jewellery, even those found in a same tomb, often contain items made by several goldsmiths, at different times, using different technologies and by exploiting different (and small) sources of gold. In addition, documentary sources make often information available on coinages issued over time.

Despite all the analytical difficulties raised by reuse and recycling of gold objects in the past, when an appropriate analytical protocol is established and the specificities of the gold objects are taken into account, the results obtained allow, from my point of view, a better understanding of the use in the past of such an amazing material as gold.

\section{REFERENCES}

Archi, A., 2002, Jewels for the Ladies of Ebla, Zeitschrift für Assyriologie und Vorderasiatische Archäologie, 92, 161-99.

Archi, A., 2015, Ebla and its archives, Walter de Gruyter Inc., Boston and Berlin.

Avramova, M., 1991, Gold and copper jewellery from the Chalcolithic cemeteries near the village of Durankulak, Varna District, In Découverte du metal (eds. J.P. Mohen and C. Eluère), Paris, Picard, 43-8.

Bartlett, P., Yoon, D. and Pliego, R., 2017, Weight, Fineness, and Debasement in Visigothic Tremisses from Theudis to Leovigild, American Journal of Numismatics, 29, 149-212.

Benson, E., 2001, Why Sacrifice?, In Ritual Sacrifice in Ancient Peru (eds. E.P. Benson and G. Cook), Austin, University of Texas, 1-20.

Bietak, M., 1996, Avaris: Capital of the Hyksos. Recent Excavations, The Trustees of the British Museum, London.

Blet-Lemarquand, M. and Duyrat, F., 2020, Elemental analysis of the Lydo-Milesian electrum coins of the Bibliothèque nationale de France using LA-ICP-MS, In White gold: studies in early electrum coinage (eds. P. van Alfen and U. Wartenberg), The American Numismatic Society, New York, 337-378.

Blet-Lemarquand, M., Bompaire, M. and Morrisson, C., 2010, Platine et plomb dans les monnaies d'or mérovingiennes, Revue numismatique, 166, 175-198.

Bottéro, J., 1949, Les inventaires de Qatna. Revue d'Assyriologie et d'archéologie orientale, 43, 1-40.

Boyle, R.W., 1979, The Geochemistry of gold and its deposits, Geological Survey of Canada, 280, Ottawa.

Boyle, R.W., 1987, General geochemistry of gold and types of auriferous deposits, In Gold: History and genesis of deposits (ed. R.W. Boyle), Springer, Boston, 11-21.

Brunton, G., 1937, Mostagedda and the Tasian Culture, Quaritch, London.

Cardozo, M., 1937, Um crime de lesa-arqueologia e lesa-arte, Revista de Guimarães, 47, 89-94.

Chapman, R.J., Banks, D.A., Styles, M.T., Walshaw, R.D., Piazolo, S., Morgan, D.J., Grimshaw, M.R., Spence-Jones, C.P., Matthews, T.J. and Borovinskaya, O., 2021, Chemical and physical heterogeneity within native gold: implications for the design of gold particle studies, Mineralium Deposita, https://doi.org/10.1007/s00126-020-01036-x

Codine-Trécourt, F., 2014, Les monnaies mérovingiennes modifiées à des fins non monétaires, Revue numismatique, 171, 497547.

Cooper, A., Garrow, D. and Gibson, C., 2020, Spectrums of depositional practice in later prehistoric Britain and beyond. Grave goods, hoards and deposits 'in between', Archaeological Dialogues, 27, 135-157.

Craddock, P.T., 1999, Reconstruction of the Salt Cementation Process at the Sardis Refinery, In King Croesus' Gold (eds. A. Ramage and P. Craddock), British Museum Press, London, 200-211.

Craddock, P.T., Cowell, M.R. and Guerra, M.F., 2005, Controlling the composition of gold and the invention of gold refining in Lydian Anatolia, Der Anschnitt, 18, 67-77.

Craddock, P.T., Cowell, M.R., Hook, D., Hughes, M. and La Niece, S., 2010, Change and stasis: the technology of Dark Age metalwork from the Carpathian Basin, British Museum Technical Research Bulletin, 4, 55-65.

Duval, A., Eluère, C., Hurtel, L. and Tallon, F., 1987, La Pendeloque au chien de Suse. Étude en laboratoire d'une brasure antique, Revue du Louvre, 3, 176-9.

Eshel, T., Yahalom-Mack, N., Shalev, S., Tirosh, O., Erel, Y. and Gilboa, A., 2018, Four Iron Age silver hoards from Southern Phoenicia: From bundles to hacksilber, Bulletin of the American Schools of Oriental Research, 379, 197-228. 
Filip, J., 1948, La Tchécoslovaquie préhistorique, introduction aux études préhistoriques, Vytiskla Stâtni Tiskârna v Praze, Prague.

Fischer-Bühner, J., 2010, Metallurgy of gold, In Gold, science and applications (eds. C. Corti and R. Halliday), CRC Press, Taylor \& Francis Group, 123-59.

Fitton, J.L., Meeks, N. and Joyner, L., 2009, The Aigina treasure: catalogue and technical report, In The Aigina Treasure, Aegean Bronze Age jewellery and a mystery revisited (ed. J.L. Fitton), The Trustees of the British Museum, London, $17-31$.

Fleming, R.W., 2014, Visual perception of materials and their properties, Vision Research, 94, 62-75.

Gale, N.H. and Stos-Gale, Z.A., 1981, Ancient Egyptian silver, Journal of Egyptian Archaeology, 67, 103-115.

Garcia Bellido, M.P., 2011, Hackgold and hacksilber in protomonetary Iberia, In Barter, Money and Coinage in the Ancient Mediterranean (eds. M.P. García-Bellido, L. Callegarin and A. Jiménez Diéz), CSIC, Madrid, 121-135.

Gilles, K.J., 2013, Der römische Goldmünzenschatz aus der Feldstraße in Trier, Trierer Zeitschrift 34, Rheinisches Landesmuseum, Trier.

Glaus, R., Koch, J. and Günther, D., 2012, A portable laser ablation sampling device for elemental fingerprinting of objects outside the laboratory with LA-ICPMS, Analytical Chemistry, 84, 5358-5364.

Glaus, R., Dorta, L., Zhang, Z., Ma, Q., Berke, H. and Günther, D., 2013, Isotope ratio determination of objects in the field by portable laser ablation sampling and subsequent multicollector ICPMS, Journal of Analytical and Atomic Spectrometry, 28, 801-809.

Golani, A. and Sass, B., 1998, Hoards of silver jewelry from Tel Miqne-Ekron, Bulletin of the American Schools of Oriental Research, 311, 57-81.

Gondonneau, A. and Guerra, M.F., 2002, The circulation of precious metals in the Arabic Empire: the case of the Near and the Middle East, Archaeometry, 44, 573-599.

Gondonneau, A., Roux, C. and Guerra, M.F., 2000, La frappe de la monnaie d'or à l'époque de l'expansion musulmane et les mines d'or de l'ouest de l'Afrique, In Proceedings of XII. Internationaler Numismatischer Kongress (eds. B. Kluge and B. Weisser), Staatliche Museen zu Berlin, 1264-1274.

Gondonneau, A., Nicolet-Pierre Roux, H. and Guerra, M.F., 2002, The Persian and Macedonian gold. From Croesus to Alexander the Great, In Archaeometry 98 (eds. E. Jerem and K.T. Biró), BAR International Series, 1043, Archaeopress, Oxford, 369-374.

Grierson, P., 1982, Byzantine coins, Methuen \& Co Ltd, London.

Grimwade, M., 2009, Introduction to Precious Metals. Metallurgy for Jewellers \& Silversmiths, Brynmorgen Press Brunswick, USA.

Guerra, M.F., 2000, Em busca da origen do ouro dos Visigodos através dos seus elementos traço, In Homenagem a Mário Gomes Marques (eds. M.C. Hipólito, D.M. Metcalf, J.M.P. Cabral and M. Crusafont i Sabater), Instituto de Sintra, 223-251.

Guerra, M.F., 2004, The circulation of South American precious metals in Brazil at the end of the $17^{\text {th }}$ century, Journal Archaeological Science, 31, 1225-1236.

Guerra, M.F., 2005, The circulation of gold in the Portuguese area from the $5^{\text {th }}$ to the $18^{\text {th }}$ century, In Ancient gold technology: America and Europe (eds. A. Perea, I. Montero Ruiz and O. García-Vuelta), Anejos de AespA, 32, 423-431.

Guerra, M.F., 2008, An overview on the ancient goldsmith's skill and the circulation of gold in the past: the role of X-ray based techniques, X-ray Spectrometry, 37, 317-327.

Guerra, M.F., 2014a, Role of radiation physics in the study and authentication of ancient gold work, Radiation Physics and Chemistry, 95, 356-361.

Guerra, M.F., 2014b, La circulation des objets en or, In Circulation et provenance des matériaux dans les sociétés anciennes. La contribution des méthodes archéométriques (eds. P. Dillmann and L. Bellot-Gurlet), Archives Contemporaines, Paris, 165-178.

Guerra, M.F., 2020, Physicochemical approaches to gold and silver work: an overview, In Chemical Analysis in Cultural Heritage (eds. L. Sabbatini and D. van der Werf), De Gruyter, Berlin and Boston, 307-330.

Guerra, M.F., 2021, Towards a conclusion: Qurna in context, In Ancient Egyptian gold. Archaeology and science in jewellery (eds. M.F. Guerra, M. Martinón-Torres and S. Quirke), Cambridge, upcoming.

Guerra, M.F. and Magro, F.A.C., 2000, O ouro da India colonial: uma primeira tentativa de caracterização, Actas do $V$ Congresso Português de Numismática, Associação Numismática de Portugal, Lisbon, 89-108.

Guerra, M.F. and Nuñez-Regueiro, P., 2012, Indigenous silver jewellery of Northern Patagonia, X-Ray Spectrometry, 41, 342349

Guerra, M.F. and Nuñez-Regueiro, P. (eds.), 2017, La orfebrería en los Andes en la época inca, Institut Français d'Etudes Andines, Lima.

Guerra, M.F. and Pagès, S., 2019, On the way to the New Kingdom. Analytical study of Queen Ahhotep's gold jewellery, Journal of Cultural Heritage, 36, 143-152.

Guerra, M.F. and Roux, C., 2002, L'or de la Péninsule ibérique des invasions à la Reconquista. Circulation monétaire des Wisigoths aux rois chrétiens, Revue d'Archéométrie, 26, 219-232.

Guerra, M.F. and Stutz, F., 2019, La bague de la sépulture 11, In Trois sépultures mérovingiennes d'exception à Saint-Dizier la Tuilerie (ed. M.C. Truc), Craham, Presses universitaires de Caen, 103-105.

Guerra, M.F. and Tissot, I., 2021. Analytical study of Bronze Age goldwork from Northwest Iberia, JAS Reports, submitted 2021.

Guerra, M.F., Calligaro, T. and Perea, A., 2007, The treasure of Guarrazar. Tracing the gold supplies in the Visigothic Iberian Peninsula, Archeometry, 49, 53-74.

Guerra, M.F., Martinón-Torres, M. and Quirke, S. (eds.), 2021a, Ancient Egyptian gold. Archaeology and science in jewellery, Cambridge, upcoming. 
Guerra, M.F., Martinón-Torres, M. and Quirke, S., 2021c, First Intermediate Period goldwork from Qau and Badari, In Ancient Egyptian gold. Archaeology and science in jewellery (eds. M.F. Guerra, M. Martinón-Torres and S. Quirke), Cambridge, upcoming.

Guerra, M.F., Fischer, M., Radtke, M. and Reinholz, U., 2017, Inca figurines from the Ethnologisches Museum in Berlin: study of some typical and atypical productions, Bulletin de l'Institut Français d'Etudes Andines, 46, 221-252.

Guerra, M.F., Sierra, J.C., Zamalloa, M.A. and Vetter, L. 2021b, Ofrendas incas en oro y plata: estudio tecnológico de estatuillas antropomorfas y zoomorfas miniatura de la región del Cusco (Perú), In Metalurgia precolombina (eds. R. Lleras and L. Vettter), Institut Français d'Etudes Andines, Lima, in press.

Harding, A.E., 2000, European societies in the Bronze Age, Cambridge University Press.

Heesch, J. van, 2017, Coin hoards as evidence of tragedies, some general remarks on the North of Gaul ( $3^{\text {rd }}$ century AD), Journal of Ancient History and Archaeology, 1, 263-275.

Howgego, C., 1995, Ancient history from coins, Routledge, London.

Humphrey, N., 1976, The colour currency of Nature, In Colour for Architecture (eds. T. Porter and B. Mikellides), StudioVista, London, 95-98.

Ivanov, I., 1982, The Varna Chalcolithic necropolis, In The First Civilization in Europe and the Oldest Gold in the World (eds. N. Egami, T. Hayashi and A. Hori), Japan, Nippon Television Network Cultural Society, 21-4.

Jansen, M., Hauptmann, Klein, K., and Zettler, R.L., 2021, Trace Elements and Isotopes: The Origin of Gold from Ur from a Geochemical Point of View, In Ur in the Twenty-First Century CE (eds. G. Frame, J. Jeffers and H. Pittman), Eisenbrauns, University Park, Pennsylvania, 273-292.

Jansen, M., Aulbach, S., Hauptmann, A., Höfer, H.E., Klein, K., Krüger, M. and Zettler, R.L., 2016, Platinum group placer minerals in ancient gold artifacts. Geochemistry and osmium isotopes of inclusions in Early Bronze Age gold from Ur/Mesopotamia, Journal of Archaeological Science, 68, 12-23.

Joannès, F., 1989. La culture matérielle à Mari IV : les méthodes de pesée. Revue d'Assyriologie et d'archéologie orientale, 83, 113-52.

Jonson, T., Blet-Lemarquand, M. and Morrisson, C., 2014, The Byzantine Mint in Carthage and the Islamic Mint in North Africa, Revue numismatique, 171, 655-699.

Joseph, H.C., 1928, La Platería araucana, Anales de la Universidad de Chile, Ballcells \& Co, Santiago.

Kay, P., 2016, Rome's Economic Revolution, Oxford University Press.

Labrousse, M. and Lafaurie, J., 1987, Trésor de monnaies mérovingiennes du VIIe siècle trouvé à Montréal (Gers) lors des fouilles de la villa de Séviac, Bulletin de la Société Française de Numismatique, 6, 222-227.

Lafaurie, J., 1971, Catalogue des monnaies trouvées au cours des fouilles de la nécropole d'Hérouvillette, Archéologie médiévale, 1, 173-187.

Lafaurie, J., 1984, Trésor de monnaies d'or du Ve siècle trouvé en 1803 à Combertault (Côte-d'Or), Revue numismatique, 26, $145-160$.

Lemasson, Q., Moignard, B., Pacheco, C., Pichon, L. and Guerra, M.F., 2015. Fast mapping of gold jewellery from ancient Egypt with PIXE: searching for hard-solders and PGE inclusions, Talanta 143, 279-286.

Le Rider, G. Le monnayage d' argent et d'or de Philippe II frappé en Macédoine de 359 à 294, E. Bourgey, Paris, 1977.

Le Rider, G. and Verdan, S., 2002, La trouvaille d'Érétrie: réserve d'un orfèvre ou dépôt monétaire?, Antike Kunst, 45, 133152.

Macleod, A., 2011, Progress in optical coatings, In Advances in optical thin films IV (eds. M. Lequime, H.A. Macleod and D. Ristau), Proc. of SPIE, 816802.

Manville, H.E., 2000, The Bank of England countermarked dollars, 1797-1804, British Numismatic Journal, 70, $103-117$.

Matsumoto, T., Fukudak, K. and Uchikawa, K., 2016, Appearance of gold, silver and copper colors of glossy object surface, International Journal of Affective Engineering, 15, 239-47.

Meeks, N.D. and Tite, M.S., 1980, The analysis of platinum-group element inclusions in gold antiquities, Journal of Archaeological Sciences, 7, 267-275.

Metcalf, D.M. and Merrick, J.M., 1967, Studies in the composition of early medieval coins, The Numismatic Chronicle, 7, $167-181$.

Miniaci, G., La Niece, S., Guerra, M.F. and Hacke, M., 2013, Analytical study of the first royal Egyptian heart-scarab, attributed to a Seventeenth Dynasty king, Sobekemsaf, British Museum Technical Research Bulletin, 7, 53-60.

Moles, N.R., Chapman, R.J. and Warner, R.B., 2013, The significance of copper concentrations in natural gold alloy for reconnaissance exploration and understanding gold-depositing hydrothermal systems, Geochemistry: Exploration, Environment, Analysis, 13,115-130.

Montet, P., 1956, La stèle du roi Kamose, C. R. Séances Académie Inscriptions Belles-Lettres, 1, 112-120.

Mørkholm, O., 1991, Early Hellenistic coinage. From the Accession of Alexander to the Peace of Apamea (eds. P. Grierson and U. Westermark), Cambridge University Press.

Morrisson, C., Poirier, J., Callu, J.P., Halleux, R. and Brenot, C., 1985. L'or monnayé : purification et altération de Rome à Byzance, Cahiers Ernest-Babelon, Paris.

Motoyoshi, I., Nishida, S., Sharan, L. and Adelson, E.H., 2007, Image statistics and the perception of surface qualities, Nature, 447, 206-209.

Nevolko, P.A., Kolpakov, V.V., Nesterenko, G.V. and Fominykh, P.A., 2019, Alluvial-placer gold of Northwestern Salair: Composition, types, and mineral microinclusions, Russian Geology and Geophysics, 60, 67-85.

Nocete, F., Sáez, R., Navarro, A.D., San Martin, C., Gil-Ibarguchi, J.I., 2018, The gold of the Carambolo Treasure: New data on its origin by elemental and lead isotope analysis, Journal of Archaeological Science, 92, 87-102.

Novak, M., 2004, The chronology of the Royal Palace of Qatna, Ägypten und Levante, 14, 299-317.

Nuñez-Regueiro, P. and Guerra, M.F., 2016, Los aros de plata de Patagonia septentrional: aportes de la colección Henry de la Vaulx (1896) sobre forma, tecnología y metalurgia, Chungara, 48, 331-345. 
Oakley, P., 2017, Is gold jewelry money?, Social Analysis: The International Journal of Anthropology, 61, 17-30.

Ogden, J.M., 1977, Platinum Group metal inclusions in ancient gold artifacts, Journal of the Historical Metallurgical Society, 11, 53-72.

Okazawa, G., Koida, K. and Komatsu, H., 2011, Categorical properties of the color term "GOLD", Journal of Vision, 11, 119.

Perea, A., 1994, Proceso de mercantilización en sociedades premonetales, Archivo Español de Arqueología, 67, 3-14.

Pérez-García, L.C, Sánchez-Palencia, F.J. and Torres-Ruiz, J., 2000, Tertiary and Quaternary alluvial gold deposits of Northwest Spain and Roman mining (NW of Duero and Bierzo Basins), Journal of Geochemical Exploration, 71, 225240.

Périn, P., Calligaro, T., Buchet, L., Cassiman, J.J., Darton, Y., Gallien, V., Poirot, J.P., Rast, A., Rücker, C. and Vallet, F., 2005, La tombe d'Arégonde. Nouvelles analyses en laboratoire du mobilier métallique et des restes organiques de la défunte du sarcophage 49 de la basilique de Saint-Denis, Antiquités Nationales, 37, 181-206.

Piña, R., 2019, The Ni-Cu-(PGE) Aguablanca Ore Deposit (SW Spain), SpringerBriefs in World Mineral Deposits.

Pingel, V., 1992. Die vorgeschichtlichen Goldfunde der Iberischen Halbinsel - Eine archäologische Untersuchung zur Auswertung der Spektralanalysen. Madrider Forschungen, 17, W. de Gruyter, Berlin.

Poirier, J., 1983, Contribution à l'analyse de l'or antique. Application aux monnayages du monde méditerranéen du IIe au XVI siècles, Ph.D. thesis, University of Orléans, France.

Ponting, M.J., 2020, Recycling and Roman silver coinage, In Recycling and Reuse in the Roman Economy (eds. C.N. Duckworth and A. Wilson), Oxford University Press, 265-284.

Pop, D., Ionescu, C., Forray, F., Tămaş, C.G. and Benea, M., 2011, Transylvanian gold of hydrothermal origin: an EMPA study in an archaeological provenancing perspective, European Journal of Mineralogy, 23, 911-923.

Popescu, G.C., Ilinca, G., Neacsu, A. and Verdes, G., 2014, The Gold Museum of Brad. Characterization of native gold samples and of other minerals, Romanian Journal of Mineral Deposits, 86, 1-122.

Radtke, M., Buzanich, G., Guilherme, A., Reinholz, U., Riesemeier, H., Scharf, O., Scholz, P. and Guerra, M.F., 2016, Double dispersive X-ray fluorescence (D2XRF) based on an energy dispersive pnCCD detector for the detection of platinum in gold, Microchemical Journal, 125, 56-61.

Rankin, W.J., 2011. Minerals, metals and sustainability: meeting future material needs, CRC Press, Balkema, Leiden.

Rapson, W.S., 1990. The metallurgy of the coloured carat gold alloys, Gold Bulletin, 23, 125-33.

Reinhard, J. and Ceruti, C., 2005, Sacred Mountains, Ceremonial Sites, and Human Sacrifice Among the Incas, Archaeoastronomy, 19, 1-43.

Reisner, G.A., 1923, Excavations at Kerma VI, Harvard African Studies, Peabody museum of archaeology and ethnology, Cambridge.

Roberts, E.F.I. and Clarke, K.M., 1979, The colour characteristics of gold alloys, Gold Bulletin, 12, 9-19.

Roux, C. and Guerra, M.F., 2000, La monnaie almoravide : de l'Afrique à l'Espagne, Revue d'Archéométrie, 24, 39-52.

Ruiz-Galvez, M., 1995, From gift to commodity. The changing meaning of precious metals in the later Prehistory of the Iberian Peninsula, In Prehistoric gold in Europe: Mines, Metallurgy and Manufacture (eds. G. Morteani and J.P. Northover), Springer, Dordrecht, 45-63.

Shiraishi, T. and Tilley, R.J.D., 2014, An estimation of the reflectivity of some monophasic binary gold alloys, Gold Bulletin 47, 75-82.

Sierra, J.C. and Guerra, M. F., 2017, Estudio tecnológico de las estatuillas antropomorfas de los tupus miniatura del hallazgo de Paucartambo (Cusco, Peru), Bulletin de l'Institut Français d'Etudes Andines, 46, 151-170.

Singer, G.S., 2015, Small ingots and scrap metal in the Eastern Mediterranean during the Late Bronze Age, In There and Back Again - the Crossroads II (eds. J. Mynarova, P. Onderka and P. Pavuk), Charles University, Prague, 85-127.

Spufford, P., 1988, Money and its use in Medieval Europe, Cambridge University Press.

Standish, C.D., Dhuime, B., Hawkesworth, C.J. and Pike, A.W.G., 2015, A Non-local Source of Irish Chalcolithic and Early Bronze Age Gold, Proceedings of the Prehistoric Society, 81, 149-177.

Thavapalan, S., 2020. The Meaning of Color in Ancient Mesopotamia, Culture and history of the Ancient Near East, 104, Brill, Leiden and Boston.

Thompson, C.M., 2003, Sealed silver in Iron Age Cisjordan and the 'invention' of coinage, Oxford Journal of Archaeology, 22, $67-107$.

Tilley, R.J.D., 2011, Colour and the optical properties of materials, John Wiley \& Sons Ltd.

Todd, J.T. and Norman, J.F., 2018, The visual perception of metal, Journal of Vision, 18, 1-17.

Thoury, M., Mille, B., Séverin-Fabiani, T., Robbiola, L., Réfrégiers, M., Jarrige, J.-F. and Bertrand, L., 2016, High spatial dynamics-photoluminescence imaging reveals the metallurgy of the earliest lost wax-cast object, Nature Communications, 7, 13356.

Troalen, L.G., Tate, J. and Guerra, M.F., 2014, Goldwork in Ancient Egypt: workshop practices at Qurneh in the $2^{\text {nd }}$ Intermediate Period, Journal of Archaeological Science, 50, 219-26.

Troalen, L.G., and Guerra, M.F., 2016, Gold from the tomb of Scribe Beri: a comparative analytical approach to the New Kingdom gold grave goods from Riqqa (Egypt), Applied Physics A, 122, 210-216.

Troalen, L.G., Tissot, I., Maitland, M. and Guerra, M.F., 2015, Jewellery of an Egyptian young girl: Middle Kingdom goldwork from tomb 72 in Harageh, Historical Metallurgy, 49, 75-96.

Troalen, L.G., Guerra, M.F., Maitland, M., Ponting, M. and Price, C., 2019, Analytical study of the Middle Kingdom group of gold jewellery from tomb 124 at Riqqa, Egypt, X-ray Spectrometry, 48, 586-596.

Vetter, L., 2018, La orfebrería inca en la costa peruana, Cuadernos del Qhapaq Ñan, 6, 66-93.

Vetter, L. and Guerra, M.F., 2017, Los tupus y figurinas de plata inkas: una aproximación a sus aleaciones, Bulletin de l'Institut Français d'Etudes Andines, 46, 171-192.

Wieck, D., 1969, Aesthetic symbols, Philosophy East and West, 19, 327-342. 
Wilkinson, A., 1971, Ancient Egyptian Jewellery, Methuen, London.

Wood, H., 1914, The coinage of the West Indies: With especial reference to the cut and counterstamped pieces, American Journal of Numismatics, 48, 89-128.

Yalçın, Ü., 2017, The beginnings of metal use in West Asia, In Ancient West Asian Civilization (eds. A. Tsuneki, S. Yamada and K. Hisada), Singapore, Springer Science, 115-30.

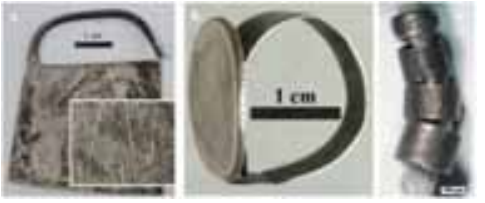

Figure 1 -Mapuche jewellery: (a) earring with removed decoration to avoid reshaping (with a detail) and (b) finger-ring consisting of a wear-used coin soldered onto a hoop. (c) Egyptian tubular and ring-shaped beads. (Images M.F. Guerra)

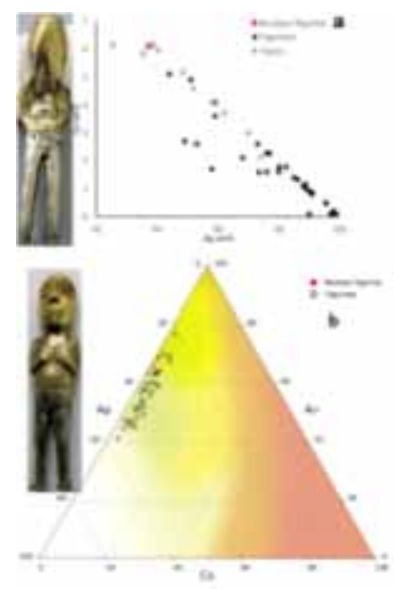

Figure 2 - The composition of the two parts of a bicolour Inca figurine compared to data mentioned in the text obtained for traditional figurines and tupus in (a) silver and (b) gold. (Images M.F. Guerra)

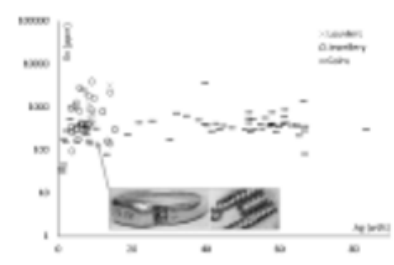

Figure 3 - The Merovingian gold finger-ring and beads from Louviers and their amounts of Ag and Sn compared to those published (mentioned in the text) for Merovingian gold jewellery and coins. (Images M.F. Guerra)

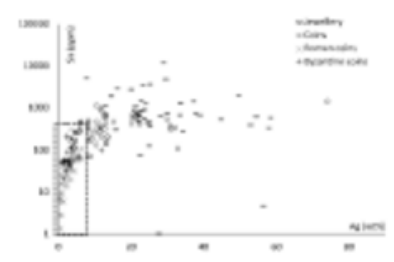

Figure 4 -The amounts of $\mathrm{Ag}$ and $\mathrm{Sn}$ (references in the text) contained in Visigothic gold jewellery and coins compared to Roman and Byzantine gold coins (inside the rectangle).

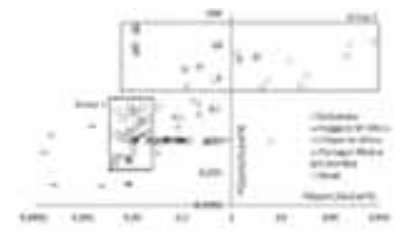

Figure 5 - The amounts of Pd and Pt normalised to the amount of gold (references in the text) obtained for jewellery, coins and ingots from Salcombe, for West African nuggets and dinars, and for Colombian, Brazilian and Portuguese coins and ingots. 